Gelanggang Pendidikan Jasmani Indonesia

\title{
PERKEMBANGAN AKTIVITAS OLAHRAGA SENAM AEROBIK DALAM MENINGKATKAN KEBUGARAN MASYARAKAT KOTA SURAKARTA
}

\author{
Karlina Dwijayanti ${ }^{1}$, Rika Yuni Ambarsari ${ }^{2}$ \\ Universitas Tunas Pembangunan Surakarta
}

\section{Info Artikel}

Sejarah Artikel:

Diterima Desember 2017

Disetujui Februari 2018

Dipublikasikan Agustus 2018

Keywords:

Olahraga, Senam Aerobik, Kebugaran

Abstrak

Tujuan Penelitian ini adalah untuk mendeskripsikan perkembangan Senam Aerobik di Surakarta. Metode penelitian yang digunakan adalah deskriptif kualitatif dengan pendekatan survey. Hasil analisis penelitian didapatkan hasil bahwa: Senam Aerobik dikota Surakarta berkembang dengan baik, ditandai dengan terbentuknya organisasi senam aerobik yaitu FORMI, serta sudah banyak jenis senam aerobik yang yg diajarkan diantaranya zumba, BL, poco-poco dll, keikutsertaan masyarakat dalam senam aerobik sangat tinggi, dibuktikan dengan banyaknya masyarakat yang memilih olahraga tersebut. senam aerobik sangat mudah ditemui dimana-mana, peran pemerintah dalam mengembangkan senam aerobik yaitu dengan memberikan akses yang luas bagi masyarakat melakukan aktifitas senam aerobik di ruang terbuka publik, serta acara Car Free Day (CFD) pemerintah menjalin kerjasama dengan pihak swasta dalam hal perlombaan senam dan kegiatan pelatihan senam aerobik. Dapat disimpulkan bahwa olahraga Senam Aerobik telah berkembang cukup pesat di Kota Surakarta.

\section{Abstract}

The aimed of this study is to describe the development of Aerobic Gymnastics in Surakarta. The research method used is descriptive qualitative with survey approach The result of research analysis showed that: Aerobic Gymnastics in the city of Surakarta well developed, marked by the formation of aerobic aerobic organization that is FORMI, and already many kind of aerobic aerobic which taught among others zumba, BL, pocopoco etc., public participation in aerobic gymnastics is very high, evidenced by the number of people who choose the sport. aerobic gymnastics is very easy to find everywhere, the role of government in developing aerobic gymnastics is to provide broad access for public aerobic exercise activities in public open spaces, and Car Free Day (CFD) the government establish cooperation with the private sector in the event of gymnastics and aerobic exercise training activities. It can be concluded that Aerobic gymnastics sport has grown quite rapidly in Surakarta City.
\end{abstract}

(C) 2018 Universitas Negeri Malang

\section{PENDAHULUAN}

Mayoritas penduduk yang merupakan pekerja serta daerah yang jarang tersentuh oleh olahraga, maka pemberdayaan olahraga merupakan bagian penting guna meningkatkan kualitas kesehatan masyarakat. Kualitas kesehatan melalui olahraga sulit dilakukan apabila tanpa adanya peran praktisi olahraga di dalamnya. Senam Aerobik menurut Marta Dinata (2005:5) adalah "Serangkaian gerak yang dipilih secara sengaja dengan cara mengikuti 
irama musik yang juga dipilih sehingga melahirkan ketentuan ritmis, kontinuitas dan durasi tertentu". Olahraga rekreasi adalah olahraga yang dilakukan oleh masyarakat dengan kegemaran dan kemampuan yang tumbuh dan berkembang sesuai dengan kondisi dan nilai budaya masyarakat setempat untuk kesehatan, kebugaran, dan kegembiraan. Pada pasal $19 \mathrm{Bab}$ VI UU nomor 3 tahun 2005 dinyatakan bahwa "olahraga rekreasi bertujuan untuk memperoleh kesehatan, kebugaran jasmani dan kegembiraan, membangun hubungan sosial dan atau melestarikan dan meningkatkan kekayaan budaya daerah dan nasional". Selanjutnya dinyatakan bahwa Pemerintah, pemerintah daerah dan masyarakat berkewajiban menggali, mengembangkan dan memajukan olahraga rekreasi. Kristiyanto (2012 : 6) menyatakan bahwa "olahraga rekreasi terkait erat dengan aktivitas waktu luang dimana orang bebas dari pekerjaan rutin. Waktu luang merupakan waktu yang tidak diwajibkan dan terbebas dari berbagai keperluan psikis dan sosial yang telah menjadi komitmennya. Sejalan dengan itu, "Sport for All" di dunia internasional telah semakin maju dan berkembang menjadi suatu gerakan global, yang dampaknya secara langsung dan tidak langsung telah mempengaruhi perkembangan olahraga di Indonesia, yang terbukti dengan semakin subur dan meningkatnya partisipasi masyarakat dalam berbagai kegiatan dan bentuk olahraga, baik yang asli berakar dari budaya bangsa dan dalam negeri Indonesia, maupun yang berasal dari budaya bangsa lain dari manca Negara. Atas dasar pemikiran bahwa potensi, manfaat dan kekayaan dari olahraga rekreasi dan gerakan "Sport for All", tidak hanya dari aspek olahraga, kesehatan dan budaya, akan tetapi juga dari aspek terkait yang lain dalam kehidupan bangsa Indonesia, maka pengembangan olahraga rekreasi dan gerakan "Sport for All" di Indonesia, harus ditangani dengan serius, baik oleh pemerintah di pusat dan daerah, maupun oleh organisasi olahraga dan masyarakat sendiri, melalui penetapan Visi "Indonesia Bugar 2020".

Senam aerobik adalah suatu rangkaian dari latihan - latihan aerobik seperti jogging, running, walking, dan jumping yang disusun sedemikian rupa dengan gerakan penghubung yang serasi dengan music yang menyatu dengan gerakan, dengan memperhatikan gerakangerakan lengan, pinggang, tungkai yang bisa dilakukan sendiri-sendiri atau kelompok. Senam merupakan salah satu kegiatan yang baik untuk perkembangan keberanian, kepercayaan pada diri sendiri dan keyakinan. Senam adalah suatu bentuk gerakan-gerakan tubuh yang direncanakan disusun secara teratur dengan tujuan untuk memperbaiki sikap dan bentuk badan, membina mengembangkan keterampilan serta kepribadian yang selaras. Senam yang dalam bahasa Indonesia sebagai salah satu cabang olahraga, merupakan terjemahan langsung dari bahasa inggris Gymnastics, atau Belanda Gymnastiek, Gymnastics sendiri dalam bahasa aslinya merupakan serapan dari bahasa yunani, gymnos yang berarti telanjang.

Menurut Irianto (2004:2) "kebugaran jasmani adalah kemampuan seseorang melakukan kerja sehari-hari secara efisien tanpa timbul kelelahan yang berlebihan sehingga masih dapat menikmati waktu luangnya". Pada dasarnya wujud kebugaran adalah kebugaran aerobik yang berarti daya tahan atau stamina yang menggambarkan kemampuan, bagian yang dilatih, untuk mempertahankan usaha yang keras dan lama dengan kata lain kebugaran aerobik adalah kapasitas maksimal untuk menghirup, menyalurkan dan menggunakan oksigen. Senam aerobik sudah lazim dikenal di Indonesia dan kita asosiasikan dengan pengertian daya tahan. Karena iti kita juga mengenal istilah daya tahan aerobik. Beberapa istilah lain yang saama pengertiannya adalah kapasitas aerobik, kebugaran kardiorespiratori, dan daya tahan kardiovaskular. Lebih lanjut dijelaskan yang dimaksud kebugaran aerobik adalah merupakan ukuran kemampuan jantung untuk memompa darah yang kaya oksigen kebagian tubuh lainnya dan kemampuan untuk menyesuaikan serta memulihkan dari aktivitas jasmani. Kebugaran aerobik diukur dengan memantau penyerapan oksigen maksimum yang dikenal dengan istilah $\mathrm{VO}_{2}$ maks, maksudnya seberapa efisien tubuh menggunakan oksigen selama aktivitas jasmani dengan intensitas moderat.

Untuk mewujudkan kebugaran aerobik adalah dengan latihan aerobik. latihan aerobik adalah aktivitas fisik yang dapat memacu jantung dan peredaran darah serta pernafasan yang dilakukan dalam waktu yang cukup lama sehingga menghasilkan perbaikan dan manfaat kepada tubuh.

\section{METODE}

Penelitian ini menggunakan pendekatan kualitatif deskriptif dengan jenis penelitian survey yang dimaksud dengan penelitian kualitatif deskriptif, dengan pendekatan studi kasus yaitu suatu penelitian yang digunakan secara intensif, terinci dan mendalam terhadap suatu organisasi, lembaga atau gejala tertentu. 
Ditinjau dari wilayahnya maka penelitian kasus hanya meliputi daerah atau subyek yang sangat sempit, tetapi ditinjau dari sifat penelitian, maka penelitian kasus ini lebih mendalam. Suharsimin Arikunto,(2002:12). Dalam studi kasus ini, peneliti menggunakan teknik purposive sampling dan snowball sampling. Untuk penentuan sampel penelitian dilakukan dengan purposive karena sudah diketahui ciri-cirinya. Menurut Maksum (2009:44) "purposive sampling adalah sebuah teknik pengambilan sampel yang cirri atau karateristiknya sudah diketahui cirri atausifat populasi. Data dikumpulkan dengan teknik non-tes (survey). Teknik ini digunakan untuk mengungkapkan data tentang perkembangan olahraga senam aerobik, dengan cara peneliti langsung turun ke lapangan atau daerah penelitian untuk mengamati dan mewawancarai orang-orang yang berkepentingan di daerah tersebut, adapun teknik pengumpulan data yang digunakan adalah memgkaji dokumen, wawancara, observasi

HASIL

Berdasrkan hasil penelitian dengan melakukan observasi, wawancara dan dokumentasi maka dijabarkan hasil penelitian sebagai berikut : 1) Perkembangan aktifitas olahraga senam
aerobic

Berdasarkan dari hasil observasi di lapangan serta wawancara dengan beberapa pihak yang terkait tentang bagimana perkembangan senam aerobik yang ada di Kota Surakarta. Hingga saat ini olahraga senam aerobik termasuk dalam olahraga yang dikategorikan dalam olahraga rekreasi, walaupun ada juga senam aerobik yang sifatnya dilombakan. Senam aerobik sendiri bisa dilakukan oleh siapa saja baik wanita atupun pria, akan tetapi kebanyakan dilakukan oleh wanita. Senam aerobik ini berkembang dikarenakan oleh bebrapa faktor yang mendukung diantaranya adalah olahraga ini mempunyai tingkatan gerakan, gerakangerakan yang selalu berkembang, serta dengan banyaknya sekali instruktur atau pelatih senam aerobik

Dari sisi yang lain juga banyak kenapa perkembangan olahraga senam aerobik ini sangat cepat salah diantaranya adalah kesadaran masyarakat untuk mencari alternatif olahraga yang cepat berkeringat juga sehat. Instruktur senam aerobik yang ada juga semakin berkembang bisa dilihat dari intensitas mereka dalam memberikan kegiatan senam aerobik, dimana para instruktur bisa melakukan senam aerobik yang cukup banyak dalam waktu 1 minggu

Para instruktur ini sekarang sudah tersebar di berbagai tempat, kegiatan senam yang ada di Kota Surakarta semisal sanggar dan acara-acara tertentu. Sekarang bayak instansi atau organisasi yang dalam kegiatannya mengadakan agenda senam aerobik biasanya ketika instansi ingin mendekatkan dengan para anggotanya biasanya olahraga dengan senam aerobik, ataupun ketika melakukan promosi mereka memanfaatkan dengan menambahi kegiatan senam aerobik.

\section{2) Kegiatan Senam Aerobik di Kota Surakarta}

Masyarakat di Kota Surakarta sekarang bisa melaksankan kegiatan senam aerobik bisa dikatakan sangat mudah, karena ada ruang terbuka yang disediakan oleh pemerintah Kota Surakarta untuk melaksanakan olahraga. Senam aerobik sekarang bisa dilaksanakan dimanapun baik dilingkungan kampung atupun dilingkunagn masyarakat Kota. Kegiatan senam aerobik sekarang mulai banyak dilaksanakan dalam-masyarakat seperti contoh kegiatan senam aerobik yang dilaksanakan oleh masyarakat minimal 1 bulan sekali, akan tetapi masih banyak kendala diantaranya adalah kesibukan dari para masyarakat serta kegiatan ini istilahnya hanya sebagi hiburan

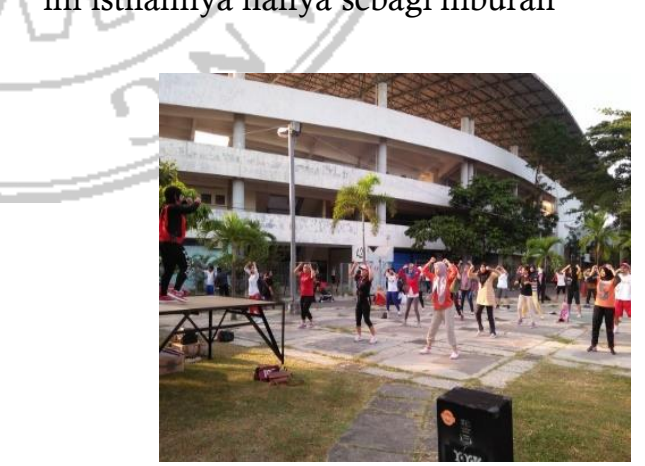

Gambar 1. Kegiatan Senam Aerobik

Fasilitas-fasilitas baik yang dimiliki oleh pemerintah kota ataupun fasilitas yang dimiliki oleh instansi tertentu juga membantu dalam kegiatan senam arobik. Fasilitsas seperti penyedian ruang terbuaka publik yang bisa diakses oleh semua masyarakat seperti di komplek stadion Manahan Sriwedari atau lapangan yang ada di setiap kecamatan. Kemudian program CAR FRE DAY (CFD) yang 
diagendakan oleh pemerintah Kota Surakarta setiap hari minggu juga menjadi tempat bagi masyarakat untuk melaksanakan kegiatan senam aerobik.

Banyak organisasi atau instansi yang memanfaatkan acara Car Free Day untuk melaksanakan kegiatan senam aerobik, disamping masyarakat menikmati suasana kota yang bebas dari kendaraan kegiatan senam aerobik ini juga bisa sebagai ajang silahturahmi ataupun tempat berkumpul sesama anggota komunitas ataupun para pelaku olahraga senam aerobik. Kegiatan -kegiatan seperti lomba senam aerobik juga banyak dilaksanakan, lomba ini biasanya dilaksanakan untuk membuat para pelaku aktifitas senam aerobik menampilkan keahlian mereka, biasanya lomba ini banyak diikuti oleh para instruktur senam.

3) Peran Pemerintah dalam Membudayakan Senam Aerobik

Senam aerobik yang merupakan kegiatan senam yang banyak dilakukan oleh masyarakat, tentunya hal ini bisa terlaksana karena kemudahan- kemudahan melaksanaknnya. Pemerintah kewajiban untuk membantu memajukan olahraga baik olahraga pendidikan, prestasi dan rekreasi seperti tertera pada Undang-undang Sistem Keolahragaan Nasional Nomor 3 tahun 2005 pada pasal 11 Hak dan kewajiban pemerintah pusat atau daerah. Ketersediaan ruang terbuka publik, sarpras olahraga serta bantuan yang lain adalah salah satu kewajiban pemerintah untuk memajukan olahraga yang tujuannya adalah untuk membudayakan hidup masyarakat supaya lebih sehat.

\begin{tabular}{|l|l|l|}
\hline No & \multicolumn{1}{|c|}{ Nama Tempat } & \multicolumn{1}{|c|}{$\begin{array}{c}\text { Luas Ruang } \\
\text { Terbuka } \mathbf{~ m}^{2}\end{array}$} \\
\hline 1 & Stadion Manahan & 170.000 \\
\hline 2 & Stadion R Maladi & 58.579 \\
\hline 3 & Gelora Manahan & 33.561 \\
\hline 4 & $\begin{array}{l}\text { Gelanggang pemuda } \\
\text { Bung Karno }\end{array}$ & 7.600 \\
\hline 5 & Velodrome Manahan & 24.011 \\
\hline 6 & Lapangan Basket & 840 \\
\hline 7 & Lapangan Voli & 2.268 \\
\hline 8 & Lapangan Tenis & $3.650,64$ \\
\hline 9 & Lapangan Bulu Tangkis & $1.634,8$ \\
\hline 10 & Lapangan Sepak Bola & 64.000 \\
\hline
\end{tabular}

\begin{tabular}{|c|c|c|}
\hline No Nama Tempat & \multicolumn{1}{|c|}{$\begin{array}{c}\text { Luas Ruang } \\
\text { Terbuka } \text { m }^{2}\end{array}$} \\
\hline \multicolumn{2}{|c|}{ Jumlah } & $366.144,44$ \\
\hline
\end{tabular}

Sumber UPTD Prasarana Olahraga DIKPORA Kota Surakarta.

Angka ruang terbuka diukur berdasarkan rasio atau perbandingan antara luas ruang terbuka yang ada di suatu wilayah dengan jumlah penduduk usia 7 tahun keatas di suatu wilayah. Berdasarkan kajian Sport Development Index standar ruang terbuka adalah $3.5 \mathrm{~m}^{2}$. Hasil dari survei ruang terbuka yang dikelola oleh pemerintah kota Surakarta seluas $366.144,44 \mathrm{~m}^{2}$ dengan perbandingan jumlah penduduk diatas usia 7 tahun 460.836 jiwa maka index aktual ruang terbuka sebesar $1,26 \mathrm{~m}^{2}$, sedangkan luas ideal ruang terbuka $3.5 \mathrm{~m}^{2} \mathrm{x}$ $460.836=1.612 .926$ sehingga ruang terbuka yang dikelola pemerintah belum dapat memenuhi nilai angka SDI. Ruang terbuka yang dikelola oleh pihak swasta sangat banyak dengan memperhatikan jumlahnya yang banyak maka bisa bilang ruang terbuka yang bisa digunakan oleh masyarakat bisa terpenuhi.

Dalam perkembangan senam aerobik ini pemerintah Kota Suarakarta juga memberikan bantuan untuk/memajukan senam aerobik. Pemerintah membentuk FORMI salah satu wadah untuk menampung olahraga-olahraga yang sifatnya rekerasi seperti senam aerobic. Bantuan yang diberikan memang tidak terlalu banyak, akan tetapi masih banyak kendala yang dihadapi. Salah satu bantuan pemerintah adalah dengan memberikan ruang terbuka publik yang bisa dimanfaatkan masyarakat untuk melaksanakan aktifitas senam aerobik seperti Car Free Day. Bantuan yang lain berupa kerjasama antar instansi atau lembaga dimana dalam agenda kegiatan biasanya diawali dengan kegiatan senam aerobik bersama. Penataran para instruktur dan juga lomba-lomba aerobik juga mungkin salah satu peran pemerintah dalam membudayakan senam aerobik.

\section{4) Keikutsertaan Masyarakat dalam Olahraga Senam Aerobik}

Kegiatan senam aerobik yang berkembang di Kota Surakarta salah satunya adalah kegiatan yang dilakasankan dalam ruang 
terbuka publik yang disediakan oleh pemerintah, salah satunya adalah arena Car Free Day. Banyak kegiatan kegiatan olahraga rekreasi yang dilaksanakan dalam arena Car Free Day tersebut salah satunya adalah kegiatan senam aerobik. Kegiatan senam aerobik yang dilakukan diacara Car Free Day adalah sebagai salah satu sarana bagi masyarakat untuk membiasakan hidup sehat karena kegiatan ini bisa diikuti oleh siapa saja tanpa harus mengeluarkan biaya. Pada dasarnya kegiatan senam aerobik yang dilaksanakn di Car Free Day ini merupakn kegiatan yang dilaksanakan oleh salah satu instansi atupun salah satu organisasi yang memang menyukai acara senam aerobik.

Kemudian kegiatan senam aerobik yang berkembang di Kota Surakarta adalah dengan semakin banyaknya tempat atau biasa disebut sebagai sanggar untuk aktifitas senam aerobik. Sanggar juga merupakan salah satu komponen dari tempat masyarakat untuk melaksanakan kegiatan senam aerobic.

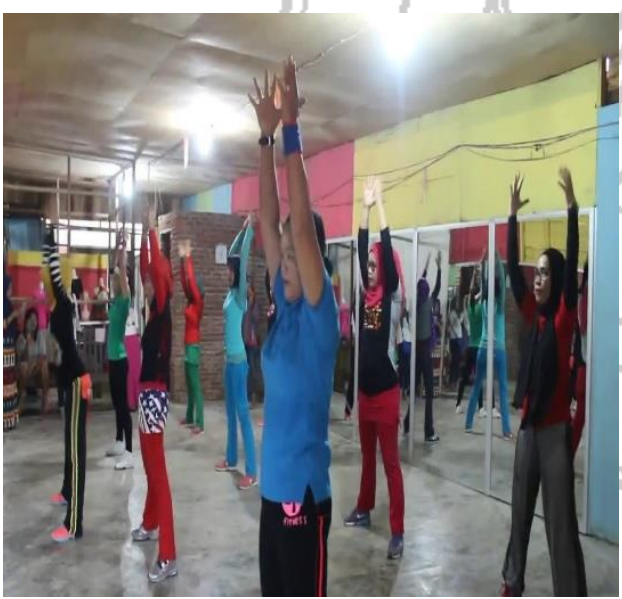

Gambar 2. Kegiatan senam Aerobik yang dilakukan disanggar Senam

\section{PEMBAHASAN}

Perkembangan senam aerobik di Kota Surakarta berdasarkan wawancara dan hasil observasi bahwa senam aerobik merupakan salah satu jenis olahraga senam dengan bantuan musik untuk melakukan gerakan sangat disukai oleh masyarakat. Senam aerobik ini berkembang dikarenakan oleh beberapa faktor yang mendukung diantaranya adalah olahraga ini mempunyai tingkatan gerakan, yang selalu berkembang, serta dengan banyaknya sekali instruktur atau pelatih senam aerobik. Dari sisi yang lain juga banyak kenapa perkembangan olahraga senam aerobik ini sangat cepat diantaranya adalah kesadaran masyarakat untuk mencari alternatif olahraga yang cepat berkeringat juga sehat, kemudian ada lagi bahwa sekarang kegiatan senam aerobik ini sangat banyak maka muncul fenomena bagaiman para pelatih dan instruktur ini memanfaatkan peluang ini untuk sebagai tempat mereka mencari nafkah. Instruktur senam aerobik yang ada juga semakin berkembang bisa dilihat dari intensitas mereka dalam memberikan kegiatan senam aerobik, dimana para instruktur bisa melakukan senam aerobik yang cukup banyak dalam waktu 1 minggu.

Sekarang banyak instansi atau organisasi yang dalam kegiatannya mengadakan agenda senam aerobik biasanya ketika instansi ingin mendekatkan dengan para anggotanya biasanya olahraga dengan senam aerobik, atupun ketika melakukan promosi mereka memanfaatkan dengan menambahi kegiatan senam aerobik. Kemudian perkembangan dalam hal jenis senam aerobik juga bisa diterima di masyarakat Kota Surakarta seperti jenis aerobik zumba, BL, poco-poco dan sebagainya. Penelitian Tya Septiana mengungkapkan bahwa, latihan senam aerobik low impact dapat meningkatkan kesegaran jasmani asal dilakukan dengan cara yang sistematis, teratur dan kontinyu. Kegiatan senam aerobik sekarang mulai banyak dilaksanakan dalam masyarakat seperti contoh kegiatan senam aerobik yang dilaksanakan oleh masyarakat minimal 1 bulan sekali, akan tetapi masih banyak kendala diantaranya adalah kesibukan dari para masyarakat serta kegiatan ini istilahnya hanya sebagai hiburan jadi kurang begitu dikembangkan, hanya semisal kalau ada waktu mari kita adakan agenda senam aerobik tetapi tidak rutin. Fasilitas-fasilitas baik yang dimiliki oleh pemerintah kota ataupun fasilitas yang dimiliki oleh instansi tertentu juga membantu dalam kegiatan senam arobik. Pemerintah memiliki kewajiban untuk membantu memajukan olahraga baik olahraga pendidikan, prestasi dan rekreasi. Ketersediaan ruang terbuka publik, sarpras olahraga serta bantuan yang lain adalah salah satu kewajiban pemerintah untuk memajukan olahraga tujuannya adalah untuk membudayakan hidup masyarakat supaya lebih sehat.

Dalam perkembangan senam aerobik ini pemerintah Kota Surakarta juga memberikan bantuan untuk memajukan senam aerobik. Pemerintah membentuk FORMI salah satu wadah untuk menampung olahraga-olahraga yang sifatnya rekerasi seperti senam aerobic.. 
Bantuan yang diberikan memang tidak terlalu banyak, akan tetapi masih banyak kendala yang dihadapi. Salah satu bantuan pemerintah adalah dengan memeberikan ruang terbuka publik yang bisa dimanfaatkan masyarakat untuk melaksanakan aktifitas senam aerobik seperti acara Car Free Day, seperti pendapat Puput Bajuri, karena ini bisa dilakukan secara bebas dan gratis meskipun berlangsung sementara. Olahraga yang paling sering dilakukan diarena Car Free Day adalah joging dan senam termasuk senam aerobik, sehingga nantinya memiliki manfaat untuk menjaga kebugaran dan kesehatan masyarakat.

\section{KESIMPULAN}

Berdasarkan hasil penelitian yang sudah Maksum, Ali. dkk. 2004. Pengkajian Sport dilakukan kemudian dapat diperoleh Development Index (SDI), Proyek kesimpulan sebagai berikut : $\quad$ Pengembangan dan Keserasian 1. Perkembangan senam aerobik di Kota Kebijakan Olahraga Dirjen Olahraga Surakarta berkembang dengan baik hal ini didukung dengan adanya wadah yang menaungi olahraga rekreasi di dalamnya senam aerobik yaitu FORMI. Olahrag senam aerobik juga berkembang dari berbagai jenis senam aerobik seperti aerobik zumba, BL, reege dll.

2. Keikutsertaan masyarakat dalam membudidayakan kegiatan senam aerobik di Kota Surakarta didukung oleh masyarakat. Masyarakat melaksanakan senam aerobik sebagai salah satu alternatif untuk untuk mewujudkan hidup sehat. Kegiatan senam aerobik yang bearada masyarakat salah satunya adalah kegiatan yang dilaksankan pada sanggar-sanggar senam, acara yang diselenggarakan oleh organisasi atau instansi tertentu. Senam aerobik yang dilaksanakan diruang terbuka publik seperti di acara Car Free day

Peran pemerintah dalam mendukung senam aerobik terlihat dari adanya wadah yang menaungi para pelaku olahrga rekreasi, dan juga pemerintah melakukan kerja sama dengan berbagai pihak yang terkait dengan kegiatan senam aerobik. Wujud yang dilaksanakan ialah pemerintah menyediakan ruang terbuka unruk masyarakat dan juga mengadakan pelatihan senam aerobik.

\section{DAFTAR PUSTAKA}

Arikunto, S. 2006. Prosedur Penelitian .Jakarta : PT. Asdi Mahasatya

Kemenpora. 2007. Undang-Undang Republik Indonesia Nomor 3 Tahun 2005 Tentang Sistem keolahragaan Nasional. Biro Humas Dan Hukum : Jakarta.

Kristiyanto, Agus. 2012. Pembangunan Olahraga Untuk Kesejahteraan Rakyat Dan Kejayaan Bangsa. Surakarta: Yuma Pustaka serta lomba-lomba yang terkait dengan kegiatan Depdiknas dan Pusat Studi Olahraga lembaga Penelitian Universitas Surabaya : Jakarta

Marta Dinata. 2003. Senam Aerobik dan Peningkatan Kesegaran Jasmani.Lampung : Cerdas Jaya

Marta Dinata. 2005. Rahasia Latihan Sang Juara Menuju Prestasi Dunia. Jakarta:Penerbit Cerdas Jaya

Pekik i, Djoko. 2004. Panduan praktis Berolahraga Untuk Kebugaran Dan Kesehatan. Yogyakarta: Andi Ofset 